\title{
ОСОБЛИВОСТІ ПОВЕРНЕННЯ ВІЙСЬКОВОСЛУЖБОВЦІВ ДО МИРНОГО ЖИТТЯ ПІСЛЯ УЧАСТІ В АТО
}

\begin{abstract}
Висвітлено основні проблеми, з якими стикаються родини військовослужбовців після їхнього повернення із зони бойових дій. Проаналізовано зміни в поведінці комбатантів, етапи психологічної корекції цих змін та наведено основні правила спілкування з військовослужбовцями в їхніх родинах. Викладено міркування автора 3 приводу негативного впливу воєнної травми на психологічне здоров'я військовослужбовців та цивільних осіб, які зазнали такого травмування. Проаналізовано зарубіжну статистику негативних впливів бойових дій на психіку солдата та досвід їх мінімізації. Встановлено, що вчасно надана екстрена психологічна допомога та постійний психологічний супровід дають змогу істотно зменшити число негативних психічних проявів серед ветеранів війни. Наголошено, що існують певні правила спілкування 3 учасниками бойових дій, які повернулися додому. Незнання цих правил або нехтування ними можуть призвести до трагічних наслідків, пов'язаних 3 особливостями сприймання навколишньої дійсності учасниками бойових дій. Звертається увага на те, що система психологічної реабілітації в державі досі перебуває на стадії становлення і координується переважно громадськими та волонтерськими організаціями; наразі немає єдиної структури, яка б опікувалася підвищенням психологічної грамотності цивільного населення щодо питань наслідків перебування в осередку бойових дій та особливостей спілкування з військовими в мирному житті. Ситуація, яка склалася у зв'язку з воєнною травматизацією великої кількості військовослужбовців та цивільного населення, може не лише посилювати і так численні негативні психічні прояви, а й призводити до економічних негараздів у країні. Робиться висновок про необхідність комплексного, багатомірного підходу до розв'язання проблеми мінімізації наслідків воєнної травми на основі використання сучасних технологій та досвіду країн, які успішно розв'язують цю проблему.

Ключові слова: військовослужбовці, посттравматичний стресовий розлад, родини учасників АТО.
\end{abstract}

Постановка проблеми. У червні 2015 р., за словами Президента Петра Порошенка, у зоні АТО перебувало 60 тисяч українських військовослужбовців. Станом на серпень 2017 р., за інформацією, що надійшла від відомчих комісій щодо надання статусу учасника бойових дій особам, які брали участь у проведенні антитерористичної операції, статус учасника бойових дій надано 306199 особам [1]. Більшість із них повернулися до своїх власних родин. Але для великої кількості сімей подія повернення солдата додому обернулася несподіваним відкриттям, що за нетривалий час перебування на службі людина змінилась, і не кожній 
родині вистачає психологічної наснаги жити з цими змінами. Статистика розлучень у сім'ях військових, які повернулися з АТО, наразі не ведеться, але є безліч свідчень щодо того, що по поверненні додому після пережитих трагічних подій чимало родин, не знайшовши спільної мови, вирішують розірвати шлюб. Більшість дружин стверджують, що 3 війни чоловіки повертаються зовсім іншими, не тими, з якими вони одружувалися.

Актуальним стає питання врегулювання порядку підготовки військовослужбовців та членів їхніх сімей до повернення солдата додому через непоодинокі випадки незнання і нерозуміння членами родини військовослужбовця особливостей його поведінки в поствійськовий період та основних правил спілкування 3 ним, що призводить іноді до трагічних наслідків. Підвищення психологічної грамотності осіб, які тісно стикаються з учасниками бойових дій у мирному житті (родина, роботодавці, співробітники соціальних служб), дасть змогу мінімізувати наслідки воєнної травми і посттравматичного стресового розладу (ПТСР).

Уже є перша статистика щодо числа самогубств та смертей серед українських військових, що трапилися не внаслідок їхньої участі у воєнних діях. 3-поміж 2027 смертей військовослужбовців, зафіксованих державою у 2014-2015 роках, 597 (або майже 30\%) сталися за обставин, не пов'язаних із воєнними діями [7]. Серед них 171 самогубство та 137 смертей через нещасні випадки. (Експерти схиляються до думки, що ці явища викликані психологічними травмами та відповідними проявами ризикованої поведінки).

Аналіз останніх досліджень та публікаиій. Відомо, що воєнний стрес, зумовлений хронічною причиною, з часом поступово загострюється. Це підтверджують і сучасні дослідження, згідно з якими у частини людей, що переживають наслідки воєнної травматизації, симптоми ПТСР з часом посилюються. Серед діагностичних труднощів виявлення ПТСР і те, що він може проявитися як протягом одного місяця після травматичної події, так і через 30-40 років після неї. Таким чином, особливістю ПТСР є тенденція не тільки не зникати 3 часом, а й набувати відтак більшої вираженості [1; 5].

У науковій літературі питання ПТСР розглядають у кількох ракурсах. Так, Р. Волошин, Л. Китаєв-Смик, Р. Лазарус вивчали механізми розвитку ПТСР, його симптоматику, фази та причини розвитку; Г. Сельє обгрунтував теоретичні засади поняття ПТСР і загального адаптаційного синдрому; І. Котенєв, В. Лисенко, О. Морозов, В. Омелянович, Н. Тарабріна, О. Тимченко, С. Яковенко впроваджували в психологічну практику технології діагностики та подолання стресових 
розладів, у тому числі ПТСР; Ф. Шапіро вивчав особливості психотерапії емоційних травм [4].

Невирішені раніме частини загальної проблеми. В Україні, на жаль, досі не вироблено комплексного багатомірного підходу до розв'язання проблеми мінімізації наслідків воєнної травми. Незважаючи на те, що Кабінетом Міністрів передбачено створення в країні системи психологічної реабілітації учасників АТО з урахуванням зарубіжного досвіду функціонування таких систем у постконфліктних ситуаціях, наявна нормативна база свідчить про те, що система психологічної реабілітації в державі досі залишається на стадії становлення, координується в основному громадськими та волонтерськими організаціями. Немає також і єдиної структури підвищення психологічної грамотності цивільного населення з питань наслідків перебування в осередку бойових дій та особливостей спілкування з військовими в мирному житті [3].

В Україні реалізація державної політики у сфері психологічної реабілітації, що перебуває наразі на етапі становлення, покладена на Державну службу України у справах ветеранів війни та учасників АТО. Особливо актуальним стає питання врегулювання порядку підготовки військовослужбовців та членів їхніх сімей до повернення комбатантів додому через непоодинокі випадки незнання і нерозуміння членами родини військовослужбовця особливостей його поведінки в поствійськовий період та основних правил спілкування 3 ним, що призводить іноді до трагічних наслідків. Підвищення психологічної грамотності осіб, які тісно стикаються з учасниками бойових дій у мирному житті (родина, роботодавці, співробітники соціальних служб), дало б змогу мінімізувати наслідки воєнної травми та посттравматичного стресового розладу.

Meта cmammi: узагальнення вітчизняного та світового досвіду 3 мінімізації наслідків воєнної травматизації військовослужбовців та цивільного населення.

Виклад основного матеріалу дослідження. Військові психологи стверджують, що війна не відпускає людину навіть після ії повернення додому, і повертається вона іншою, тому що під час бойових дій військовий набуває нового, у більшості випадків травматичного, досвіду. Цей досвід допомагає йому вижити в бойових умовах, але суперечить культурним цінностям, закладеним з дитинства, де основними вимогами було не завдавати шкоди довколишнім, не вбивати і т. ін. Тобто стирається базова межа “добре-погано”, що, відповідно, призводить до психологічної травматизації і переосмислення цінностей.

Але змінюється не лише військовослужбовець, змінюються i його рідні, які залишаються вдома і також отримують травматичний досвід чекання і хвилювання за близьку людину (травма посилюється у випадку поранення або потрапляння в полон). Тому, коли військо- 
вослужбовець повертається додому, зустрічаються лише зовні незмінні, але зовсім інші особистості з новими психологічними особливостями, яким необхідно заново проходити процедуру знайомства і звикання одне до одного.

Очікуючи бажаного повернення додому, і солдат, і його рідні подумки уявляють, як це буде, заздалегідь планують і за себе, i за інших момент зустрічі. При цьому вони виходять 3 довоєнного досвіду і не враховують змін, які відбулися з ними всіма. Реальність повернення буде однозначно відрізнятися від запланованої, що спровокує нерозуміння, розчарування та інші негативні психічні реакції.

Жінки звикли жити в тривожному очікуванні весь тривалий час перебування їхніх чоловіків на сході країни. Після повернення додому не кожна може одразу вийти з "режиму" тривожності, і навіть коли чоловік ненадовго покидає домівку, наприклад, щоб зустрітися з побратимами, продовжує за нього тривожитись і виявляти надмірне піклування, часом намагаючись навіть обмежити коло його спілкування. Щоб знизити власний рівень травматизації, деякі дружини просять чоловіків не розповідати про війну, не розуміючи того, що протягом деякого часу в колишніх бійців просто немає інших тем, адже тривалий час у їхньому житті інших подій просто не було. Через це комбатанти обирають зустріч 3 друзями, які пройшли таке саме “пекло", адже вдома їх не можуть зрозуміти повною мірою. Іноді, навпаки, їм дуже важко говорити про війну через відчуття нереальності того, що там відбувалося.

Загалом виділяють n'ять особливостей, характерних як для вітчизняних, так і для іноземних учасників бойових дій: перша - це потреба бути зрозумілим довколишніми; друга - потреба стати соціально визнаним; третя - отримати більш високий соціальний статус, ніж до участі в бойових діях; четверта - неприйняття того факту, що під час перебування військового в зоні бойових дій інша частина країни продовжувала мирне існування і робила вигляд, що війни немає; п'ята зниження порогу стійкості до соціальної несправедливості.

Крім того, проявляється надчутлива пильність, навіть підозріливість. Далі - стан песимізму і недовіри. Виникає відчуття нереальності через те, що, повертаючись додому, військовий уявляє ту саму обстановку, яку він залишав перед війною, а натомість світ не стояв на місці, усе змінювалось, і потрібен час для усвідомлення змін, які відбулися. Також його поведінка стає більш агресивною, у ній можуть виявлятися неадекватні стилі, які переносяться з війни в мирний час: людина поводиться вдома так, як у зоні бойових дій, іноді не дослухаючись до оточення і не чуючи його.

Через низьку психологічну культуру нашого суспільства навіть найближчі люди не знають, як реагувати на ці поведінкові особливості 
та зміни рідної людини, не можуть для себе їх пояснити, а тому часом просто усуваються від спілкування, чим завдають військовослужбовцю ще більшої емоційної травми. За світовою статистикою, від 30 до 85\% учасників бойових дій відтак отримують посттравматичний стресовий розлад (ПТСР), який виявляється найчастіше нападами роздратованості й агресії, тягою до руйнувань і навіть убивств. Статистика поширеності ПТСР у збройних силах різних країн показує, що військовиків Канади і Великобританії цей показник становить, наприклад, 10\%, а в збройних силах США - 20\%. В Ізраїлі на цей час поширеність ПТСР серед учасників бойових дій становить $1-2 \%$, хоча початковий показник ПТСР серед ветеранів ізраїльської війни 1973 року сягав 20\% (протягом наступних 32 років він знизався до 6,8\%) [6].

Сучасна статистика самогубств серед військовослужбовців також різниться в різних країнах. У війську США наразі фіксується до 22 самогубств щодня, тоді як рівень смертності серед ізраїльських військових досить низький: від 28 випадків у 2010 р. до 21 - у 2011 р., 7 - у 2013 р. та 15 - у 2014 р. До проявів ПТСР серед колишніх військових США також можна віднести високий рівень безпритульності: $12 \%$ безпритульних США - це ветерани.

Відмінності щодо негативних посттравматичних виявів у різних країнах пов'язані передусім з організацією профілактики та надання психологічної допомоги на рівні держави. Так, в ізраїльському війську солдат обов'язково проходить психологічну підготовку, де вчиться розпізнавати симптоми гострого психологічного шоку у своїх співслужбовців та надавати необхідну екстрену психологічну допомогу ще на полі бою - до того, як шок переросте в довготривалу травму. Також військовослужбовцям постійно надається психологічна допомога: до, під час та після травматичних подій. Завдяки довірі до фахівців і доступності психологічної допомоги військовослужбовці можуть отримувати їі тоді, коли вона необхідна. Інші розвинені країни, переймаючи досвід Ізраїлю, також поступово зменшують відсоток ПТСР серед своїх військовослужбовців.

Причинами розвитку ПТСР, як відомо, можуть бути пережиті епізоди насильства, отримання каліцтва або спостерігання за тим, як хтось інший отримує тяжкі фізичні ушкодження, власна інвалідність та загроза смерті. Отже, факторами ризику виникнення ПТСР є участь у бойових діях, спостерігання насильства, смерті, горя; особисті переживання і страхи, часто викликані смертю друга або близької людини; вимушене ризикування власним життям, участь в аваріях, катастрофах; фізичні травми, контузї, черепно-мозкові травми, тобто події, пов'язані 3 війною, які важко усвідомити і прийняти. У більшості випадків вияв синдрому провокується жорстокістю, загибеллю людей, насиллям i болем. Ці події асоціюються з відчуттям жаху, почуттям безпорадності 
і невідворотності. При цьому ПТСР може виявлятися не лише безпосередньо в учасників бойових дій, а й у членів їхніх родин, волонтерів, журналістів, медиків, рятувальників і людей, що проживають на території воєнного конфлікту.

Перші ознаки захворювання, так званий гострий синдром, 3'являються протягом шести місяців після отримання травми і поступово затухають протягом наступних п'яти-шести місяців. Про хронічний перебіг синдрому можна говорити тоді, коли симптоматика не зникає більше ніж півроку. Іноді симптоми з'являються після певного прихованого періоду - через півроку й більше після травматичної ситуації - i спостерігаються ще понад півроку. Такий перебіг називають відстроченим синдромом. У цей період людина потерпає через втрату “смаку до життя”, безсоння, втрату апетиту та сексуального потягу, зміну самооцінки; у неї з'являється бажання помсти, виникають думки про самогубство, спровоковані втратою сенсу життя; мислення хворого стає “тунельним", він не йде на контакт і не піддається вмовлянням; у нього розвиваються стани марення, він бере на себе вину практично за все, що відбувається довкола. Якщо хворий переживає важку стадію, його організм виснажується, у нього спостерігаються розлади серцево-судинної діяльності, змінюється артеріальний тиск.

На думку фахівців, одужати можуть не всі пацієнти і не так швидко, як хотілося б. Дуже часто небажані спогади і видіння приходять уві сні, що призводить до порушень сну і безсоння; через брак повноцінного сну психіка хворого потерпає від додаткових надмірних перевантажень. Удень можуть виникати болючі спогади, які провокує найменша деталь, що нагадує травматичну подію (якась річ, мелодія, запах, образ тощо); іноді виникають галюцинації - людина бачить трагічні картини в режимі реального часу, приймаючи їх за дійсність. Зростає почуття провини, притаманне людям, які за певних обставин залишилися живими, а їхні друзі (родичі) загинули. У таких людей відбувається переоцінка цінностей: вони втрачають здатність радіти життю і навіть просто жити в реальному світі, а іноді, навпаки, намагаються жити не лише за себе, а й за померлого, перевантажуючи і виснажуючи свій організм.

Найбільш важкими наслідками ПТСР є думки про самогубство, які декому вдається реалізувати. Вітчизняної статистики з цього питання поки що немає, але зарубіжна свідчить, що протягом 20 років після війни у В'єтнамі через самогубства пішло із життя більше солдатів, ніж їх загинуло за роки воєнного конфлікту. У 90\% тих, хто залишився живим, розпалися сім'ї- у більшості випадків через постійні депресії, розвиток алкогольної та наркотичної залежності і т. ін. За кордоном у зв'язку із цим існує обов'язкова практика психологічної реабілітації осіб, які перебували в зоні бойових дій. 
Науково-дослідний центр гуманітарних проблем Збройних сил України наголошує на необхідності дотримуватися під час спілкування 3 військовослужбовцем, який щойно повернувся з АТО, певних поведінкових норм, дотримання яких допоможе уникнути типових помилок. Серед цих норм - ті, які допоможуть уникнути автоматичного спрацювання механізму бойового самозахисту та нещасних випадків з рідними. У перші дні після повернення не можна підходити до демобілізованого ззаду, краще наближатися збоку або спереду; краще не з'являтися перед ним раптово у безпосередній близькості. Також слід обов'язково попередити про це дітей. Необхідно намагатися не створювати раптових різких та гучних звуків у побуті (брязкання виделки по тарілці, посуду в мийці тощо); уникати (не створювати) побутових ситуацій, які можуть роздратувати демобілізованого.

Не можна в жодному разі демонструвати військовослужбовцю всі ті негативні емоції, які могли накопичитися за час його відсутності. У разі спільного перегляду телепередач краще оминати сюжети, пов'язані з війною, насильством, убивствами тощо. Доручаючи чоловікові виконати певні побутові завдання, слід стежити за тим, щоб вони не були занадто складними, особливо на початку. Під час спілкування 3 учасником бойових дій не можна примушувати його розповідати про війну, перебивати й зупиняти, коли він говорить; пот-рібно слухати його уважно, не давати оцінок почутому, не приймати рішень щодо нього (наприклад, щодо необхідності звернення до психолога) поспіхом, у невдалий момент, без попереднього уважного вислуховування; не вказувати йому що робити, не давати порад, попередньо не вислухавши уважно і не переконавшись, що він не проти їх почути.

Запобігти появі ПТСР неможливо, але надання вчасної психологічної підтримки може допомогти в ранньому самостійному подоланні наслідків розладу. ПТСР має тривалий термін лікування. Тривалість залежить від своєчасного надання допомоги спеціалістами, від підтримки родини та близьких людей, настрою хворого на одужання, його убезпеченості від подальшої психологічної травматизації. Вчасна допомога спеціалістів скорочує термін лікування вдвічі. У разі ускладнення ПТСР якимись патологічними порушеннями виникає необхідність у довічній реабілітації і психотерапевтичному лікуванні.

Проблема ПТСР в Україні не обмежується тільки військовими. За попередніми оцінками, травму війни дістали приблизно 5,5 млн громадян, у тому числі 2 млн, які проживають по обидва боки від лінії розмежування на сході, і 1,5 млн внутрішньо переміщених осіб. Більшість із них - жінки, діти і люди похилого віку.

За прогнозами науковців, сукупний травматичний досвід нації, безперечно, буде впливати не лише на психологічне здоров'я, а й на економічну ситуацію в країні. 
Висновки. Отже, обізнаність населення і військовослужбовців щодо психологічних новоутворень і ризиків перебування в АТО допомогла б уникнути багатьох трагічних наслідків, пов'язаних з особливостями сприймання навколишньої дійсності учасниками бойових дій. Також своєчасна допомога спеціалістів дала б змогу зменшити час на проведення реабілітаційних заходів, що, відповідно, зменшило б матеріальні затрати на відновлення та ресоціалізацію військових, їх повернення до мирного життя як повноцінних членів суспільства. Натомість нехтування зазначеними проблемами 3 огляду на велику кількість комбатантів, які повернулися і ще повернуться до цивільного життя після демобілізації, може призвести до наростання агресивних і невротичних тенденцій у суспільстві. Це питання, безперечно, потребує державного врегулювання. Потрібен комплексний, багатомірний підхід до розв'язання проблеми мінімізації наслідків воєнної травми з використанням сучасних технологій та досвіду країн, які вже успішно розв'язують цю проблему. Досвід Ізраїлю із цього погляду є досить актуальним для України. Крім того, маємо чималий власний досвід ветеранів Афганістану, які стали соціально успішними.

Наступний етап нашої роботи - визначити алгоритм надання екстреної психологічної допомоги та механізм подальшого психологічного супроводження військовослужбовців та членів їхніх сімей до моменту повного психологічного відновлення.

\section{Лimepamypa}

1. Діагностика, терапія та профілактика медико-психологічних наслідків бойових дій в сучасних умовах : метод. рек. / [уклад. : Волошин П. та ін.]. Київ, 2014. - 67 с.

2. Інформація щодо надання статусу учасника бойових дій. Державна служба України у справах ветеранів війни та учасників антитерористичних операцій [Електронний ресурс] / Офіційний веб-сайт Державної служби України у справах ветеранів війни та учасників антитерористичної операції. Режим доступу : http://dsvv.gov.ua/dostup-do-publichnoji-nformatsiji/ informatsiya-schodo-nadannya-statusu-uchasnyka-bojovyh-dij.html.

3. Максименко С. Д. Система психологічної реабілітації в Україні / Максименко С. Д., Сна А. І., Сичевський А. С. // Актуальні проблеми психологічної допомоги, соціальної та медико-психологічної реабілітації учасників антитерористичної операції: матеріали міжвідомч. наук.-практ. конф. (Київ, 26 травня 2016 р.) / М-во оборони України, Нац. ун-т оборони України ім. Івана Черняховського. - Київ : НУОУ, 2016. - С. 125-127.

4. Стаднік I. В. Психологічні особливості переживання посттравматичного стресового розладу (ПТСР) учасниками зони антитерористичної операції (АТО) [Електронний ресурс] / І. В. Стаднік, М. І. Мушкевич // Психологія: реальність і перспективи. - 2015. - Вип. 4. - С. 244-248. - Режим доступу : http://nbuv.gov.ua/UJRN/prp_2015_4_66. 
5. Стрес і людина: медико-психологічна допомога при стресових розладах : метод. посіб. / за ред. І. Я. Пінчук, К. Д. Бабова, А. І. Гоженка. - Київ, 2014. $-91 \mathrm{c}$.

6. Junger $S$. How PTSD Became a Problem Far beyond the attlefield [Electronic resourse] / S. Junger // Vanity Fair. - 2015. - Access mode : https://www.vanityfair. com/news/2015/05/ptsd-war-home-sebastian-junger.

7. Tabarovsky I. What Ukraine Can Learn from Other Countries' Experiences with PTSD [Electronic resourse] / I. Tabarovsky // Kennan Cable. - 2016. - № 13. Access mode: https://www.wilsoncenter.org/ publication/kennan-cable-no13what-ukraine-can-learn-other-countries-experiences-ptsd.

\section{References}

1. Voloshyn, P. \& others (2014). Diahnostyka, terapiia ta profilaktyka medykopsykholohichnykh naslidkiv boiovykh dii v suchasnykh umovakh: metodychni rekomendatsii [Diagnostics, therapy and prevention of medical and psychological consequences of combat operations in modern conditions: methodical recommendations]. Kyiv (ukr).

2. Informatsiia shchodo nadannia statusu uchasnyka boiovykh dii. Derzhavna sluzhba Ukrainy u spravakh veteraniv viiny ta uchasnykiv antyterorystychnykh operatsii [Information on the status of a participant in hostilities. State Service of Ukraine on War Veterans and AntiTerrorist Operations Participants], http://dsvv.gov.ua/dostup-do-publichnoji-nformatsiji/informatsiya-schodonadannya-statusu-uchasnyka-bojovyh-dij.html (ukr).

3. Maksymenko, S. D., Yena, A. I., \& Sychevskyi, A. S. (2016). Systema psykholohichnoi reabilitatsii v Ukraini [The system of psychological rehabilitation in Ukraine]. Aktualni problemy psykholohichnoi dopomohy, sotsialnoi ta medykopsykholohichnoi reabilitatsii uchasnykiv antyterorystychnoi operatsii: materialy mizhvidomchoi naukovo-praktychnoi konferentsii [Actual problems of psychological help, social and medical-psychological rehabilitation of antiterrorist operation participants: materials of the interdepartmental scientific and practical conference Ministry of Defence of Ukraine, National Defence University of Ukraine named after Ivan Cherniakhovskyi]. Kyiv, pp. 125-127 (ukr).

4. Stadnik, I. V. (2015). Psykholohichni osoblyvosti perezhyvannia posttravmatychnoho stresovoho rozladu (PTSR) uchasnykamy zony antyterorystychnoi operatsii (ATO) [Psychological features of the experience of post-traumatic stress disorder (PTSD) by participants of antiterrorist operation (ATO) zone]. Psykholohiia: realnist i perspektyvy [Psychology: Reality and Perspectives], 4, 244-248, http://nbuv.gov.ua/UJRN/prp_2015_4_66 (ukr).

5. Pinchuk, I., Babova, K., \& Hozhenko, A. (2014). Stres i liudyna: medykopsykholohichna dopomoha pry stresovykh rozladakh: metodychnyi posibnyk [Stress and human: medical and psychological help in stress disorders: methodical manual]. Kyiv (ukr).

6. Junger, S. (2015). How PTSD Became a Problem Far beyond the attlefield. Vanity Fair, https://www.vanityfair.com/news/2015/05/ptsd-war-homesebastianjunger.

7. Tabarovsky, I. (2016). What Ukraine Can Learn from Other Countries' Experiences with PTSD, https://www.wilsoncenter.org/publication/kennan-cable-no13what-ukraine-can-learn-other-countries-experiences-ptsd. 


\section{Dyshkant O. V. Peculiarities of Returning of Military Personnel to the Peaceful Life after Participation in ATO}

The paper shows the main problems faced by families of military personnel after their return from the combat zone, analyzes the changes in the behavior of the combatants, the stages of psychological correction of these changes and gives the primary rules of communication with military personnel in their families. The article shows the author's considerations on the negative influence of military trauma on the psychological health of military personnel and civilians who got military trauma. It is analyzed the foreign statistics of negative impacts of military actions on the soldier's psyche and the experience of their minimization. It is determined that the provision of urgent psychological assistance and constant psychological support on time have a positive impact on the percentage of negative psychic symptoms of veterans of the war. It is underlined that there are specific rules of communication with the combatants who returned home. Ignorance and neglect of them can lead to the tragic consequences related to the peculiarities of perception of the surrounding realities by combatants. It is noted that the system of psychological rehabilitation in the country is still at the stage of formation and is coordinated, mainly, by the public and volunteer organizations. There is no single structure for improving the psychological literacy of the civilian population regarding the consequences of staying in the center of combat operations and the particularities of communication with the military in the peaceful life. The situation which occurred with military traumatization of a vast number of military personnel and civilian population can lead not only to excessive negative psychic symptoms but also to economic problems in the country. A complex multidimensional approach is necessary for dealing with the issue of minimizing the effects of military trauma using modern technology and the experience of countries that successfully solve this problem.

Key words: military personnel, post-traumatic stress disorder, ATO participants' families, combatants, military trauma.

(C) Дишкант О. В. 
